\title{
Mildew fungi found in termites (Reticulitermes lucifugus) and their nests
}

\author{
A. Wójcik, B. Andres \\ Department of Wood Science and Wood Preservation, Warsaw University of Life Sciences, \\ Warsaw, Poland
}

\begin{abstract}
This paper presents the results of observation of mould growth in laboratory colonies of termites. It also attempts to determine the species of mould fungi present in the research laboratory and the main colonies and their entomopathogenic for the termites. The following four species were found in test termite colonies: Trichoderme viride, Mucor himeralis, Rhizopus nigricans, Aspergillus sp., Aspergillus flavus, Alternaria sp., Penicylium verucosum and Fusarium sp. were recognisable in test colonies with domestic and exotic wood. Morphological observations of the fungi were carried out using a microscope with a 40x magnification. The growth of mould fungi in test containers caused death of whole termite colonies.
\end{abstract}

\section{Introduction}

During the years 2010-11, at the Division of Wood Protection of Faculty of Wood Technology of WULS, a series of tests were performed, on rate of selected domestic and exotic woods and selected wood-based materials degradation caused by a European termite Reticulitermes lucifugus (Rossi). Test samples were infected by mildew fungi. The fungi propagated on termites, causing extinction of all or most termites.

It is necessary to remark high mortality rate of termites in test colonies. The cause of that should be taken into consideration; was it the weakening of insects separated from main nest and bred in $200 \mathrm{~mL}$

Correspondence: Aleksandra Wójcik, Department of Wood Science and Wood Preservation, Faculty of Wood Technology, Warsaw University of Life Sciences - WULS, 02-776 Warsaw, Nowoursynowska 159, Poland.

E-mail: aleksa.wo@gmail.com

Key words: Termites; entomopathogens; fungi; microtoxins.

Received for publication: 5 December 2013.

Revision received: 15 April 2014.

Accepted for publication: 16 January 2015.

(C) Copyright A. Wójcik and B. Andres, 2015

Licensee PAGEPress, Italy

Journal of Entomological and Acarological Research 2015; 47:2184

doi:10.4081/jear.2015.2184

This article is distributed under the terms of the Creative Commons Attribution Noncommercial License (by-nc 3.0) which permits any noncommercial use, distribution, and reproduction in any medium, provided the original author(s) and source are credited. and $500 \mathrm{~mL}$ beakers or high pathogenicity of fungi strains? Another question is how sterile colonies, prepared in accordance to Anonymous $(2005,2008)$ were infected by fungi? In order to answer these questions, research was undertaken. It was focused on determining mildew fungi species causing high mortality in test colonies as well as identifying fungi appearing in the main termite nest.

Termites feed on cellulose-rich plant tissue. However, these insects do not have enzymes necessary for cellulose and hemicelluloses digestion. Digestion of these polysaccharides occurs through microorganisms present in the alimentary tract of the insects. In intestines of the insects, the following fungi were found: Alternaria alternata (Fr) Keissel, Paecilomyces fusisporus (Saksena), Rhizopus stolonifer (Ehrenb.), as well as some species of Aspergillus and Cladosporium families (Grzywnowicz, 2002).

Some termite species provide their nests with special chambers, called fungi garden, in which special fungi are bred and then used as food for larvae. In nests of fungi breeding species the following moulds were found: Fomes sp., Acremonium sp., Fusarium sp., Stachybotrys sp., Penicylium sp. and Trichoderma sp. (Grzywnowicz, 2002). Other research isolated worker and soldier castes of Formosan subterranean termite Coptotermes formosanus (Shiraki) (Isoptera: Rhinotermitidae) with spores of three mould fungi: Aspergillus fumigatus (Fresenius), Aspergillus nomius (Kurtzman, Horn \& Hesselt) and Curvularia lunata (Boedijn). In the aforementioned works the possibility of insects and fungi coexisting and the possibility of their diet being supplemented with fungal proteins was not excluded. The possibility of a termite-fungi association is discussed by Rojas et al. (2001).

Nests may become the growth place for not only the feeding termite species, but also the rival ones. Jayasimha and Henderson (2007) showed that all fungal structures isolated from intestines and skin of the C. formosanus were antagonistic towards Gloeophyllum trabeum (Persoon), efficiently controlling growth of this Basidiomycete. Termites then can use parasitic fungi to control $G$. trabeum, the fungi competing with these community insects (Jayasimha \& Henderson, 2007).

Over 700 species of entomopathogenic fungi are known (Milner, 2000; Lenz, 2005). Species such as Paecilomyces farinosus (Holmskjold) and Paecilomyces fumosoroseus (Wize) are most common (Piontek, 1999; Mazurkiewicz-Zapałowicz, 2006; Zimmerman, 2008). Beauveria bassiana (Balsamo-Crivelli) Vuillemin and Metarhizium anisopliae (Metchnikoff) Sorokin are also regarded as harmful for ground termites (Lenz, 2005; Yanagawa et al., 2010, Sawicki, 2010). Metarhizium anisopliae (Metchnikoff) Sorokin fungus produces as many as 17 paralysing substances. Its hyphae contain large amounts of endoprotease responsible for adhesion of fungus' hyphae to the cuticle of the insect. This fungus belongs then to specialised invasive species (Mazurkiewicz-Zapałowicz, 2006). The pathogenic properties of Aspergillus flavus (Link), fungi produce aflatoxin causing mortality in various termite species (Becker et al., 1969; Zoberi \& Grace, 1990). Worldwide literature also describes mutual protection of worker-termites against translocation of harmful spores 
such as Beauveria brongniartii (Saccardo) on their bodies. Through mutual nursing, worker-termites remove spores of pathogenic fungi from their bodies. Insects recognise dangerous fungi species by their sense of smell (Yanagawa et al., 2010).

On the other hand, some termites have high resistance against fungal epizootic diseases (Boucias \& Pendland, 1996; Rosengaus et al., 1998; Myles, 2002; Shimizu \& Yamaji, 2003; Meikle et al., 2005). Such differences are caused by variations of research methods, like infection methods, concentration of spores in lab wares, quantity of tested insects, etc.

Interactions between termite and insecticidal fungi species are not fully determined and require further investigation.

\section{Materials and methods}

There were 80 beakers ( 250 or $500 \mathrm{~mL}$ ) with 250 termites workers per beaker. Samples of selected domestic woods: Pinus sylvestris (L.) and Quercus robur (L.) and exotic woods: Hopea pieeri (Hanse) and Erythrophleum fordii (Oliver) and as well as wood-based materials such as fibreboard and medium density fibreboard were used.

Mycelium and spore samples of mould fungi were acquired from the infected annual rings of wood. Biological material was incubated on nutrient agar at $27^{\circ} \mathrm{C}$. Pure fungi cultures were obtained by inoculation on MEA (Malt Extract Agar) in Petri dish. After the incubation, macroscopic and microscopic morphology using a 40x microscope was performed to identify fungi (Thom \& Raper, 1945; Raper et al., 1949; Piontek, 1999).

\section{Results and discussion}

The following mould fungi were discovered: Penicylium verucosum (Stolk et Hadlok), Mucor himeralis (Wehmer), Trichoderma viride (Pers. ex Gray), mould of Aspergillus (A. ustus or A. flavus) genre, as well as Rhizopus sp., Paecilomyces sp. and Alternaria sp. fungi. Fusarium gramirenorum (Petch) and others of Fusarium sp. genre were possibly observed as well but these species could not be isolated. Fungi of the nest appeared to be similar to fungi in test colonies of the experiment. Six mould species were bred from the nest: Aspergillus ustus (Thom et Church) (Figure 1) and probably Aspergillus flavus (Link), Fusarium sp. (possibly F. gramirenorum, T. viride, Paecilomycetes sp., and Alternaria $s p$. In the nest, there was intensive growth of Coniophora puteana (Karsten) fungus and spores of the fungus Alternaria sp. and Fusarium sp. It was also possible to determine the Penicillium verucosum species after the construction of conidia occurred as well as to find conidia of Trichoderma viride, and hülle cells characteristic of the mould Aspergillus sp.

Part of the selected insects came from the nest infected with Coniophora puteana (Karst.) fungus. Termites originating from this nest showed lighter shade of the cuticle, varying from the natural colour. Discoloration could give some indication about initial fungi infection, caused by a weakened immunological system. Weakened and infected individual insects could then transfer fungi spores on wood samples. Fungi, rapidly growing in optimal conditions (moisture and temperature factors), quickly spread to the weakest termites, isolated from their home nest. After the mycelium appeared on the termite bodies, necrobiosis occurred (Figures 1 and 2).

Some fungi species isolated from the test colonies produce toxic compounds. Numerous microtoxins are produced by Alternaria $s p$. fungi. Some dead insects were overgrown with hyphae of this species (Figures 3 and 4). The presence of Aspergillus flavus (Link), producing dangerous aflatoxin, probably caused high mortality. The afore- mentioned fungus is described in numerous articles as toxic to various insects (Becker et al., 1969; Zoberi \& Grace, 1990). Aflatoxin and other microtoxins are as well produced by Penicilium verucosum (Stolk et Hadlok) while T. viride produces trichodermin. Brownold and Flanders (2005) describe another mould species - Trichoderma harzianum (Rifai) as a known pathogen for western honeybee Apis mellifera L. Ophiocordyceps sphecocephala (Klotzsch et Berk) (Lohmeyer \& Künkele, 2006) is a parasite affecting wasps and other Hymenoptera sp.

Isolated Mucor himeralis (Wehmer) fungus infests insects through their damaged cuticle (Piontek, 1999). Their pathogenic properties are widely known, especially against younger bees (Piontek, 1999). Mucor sp. was isolated from $C$. formosanus nests. Damage to termite cuticle may have occurred during sampling for the tests. Similar damages may have also occurred during other activities related to moving the insects to test colonies, weighting or raking the soil in the main nest. As it is commonly known, damaged cuticle is one of the most important infection causes of fungi pathogens. Fungi of Mucor sp. belong to most common ground species. Strong toxic properties are also shown by Rhizopus sp. (Piontek, 1999). Other moulds isolated from the main

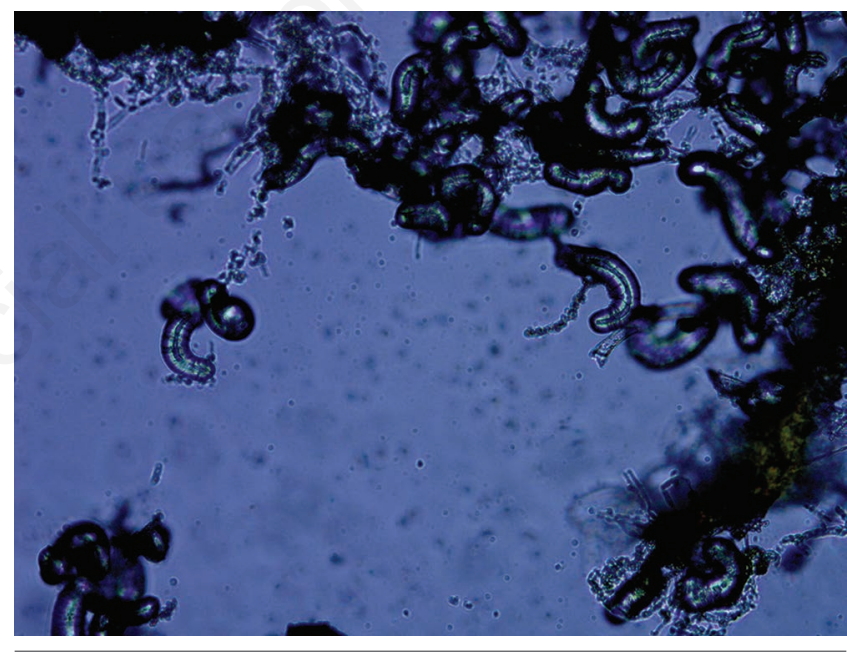

Figure 1. Aspergillus ustus.

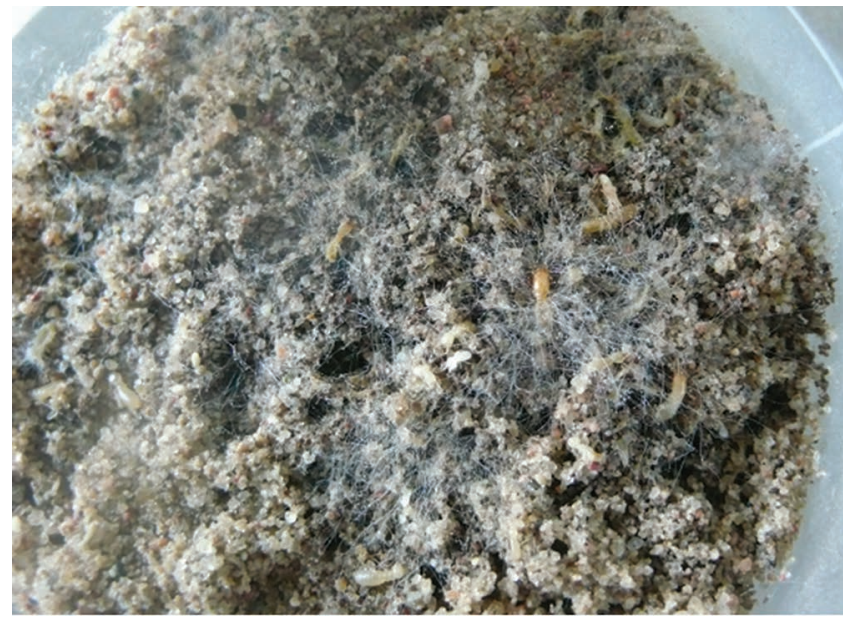

Figure 2. Beaker with termites reared on mould. 
nest or test colonies such as Paecilomyces sp. fungi are widely known as insect parasites and they are used as biological insecticides. As an example of such application, Paecilomyces fumosoroseus (Wize) may be

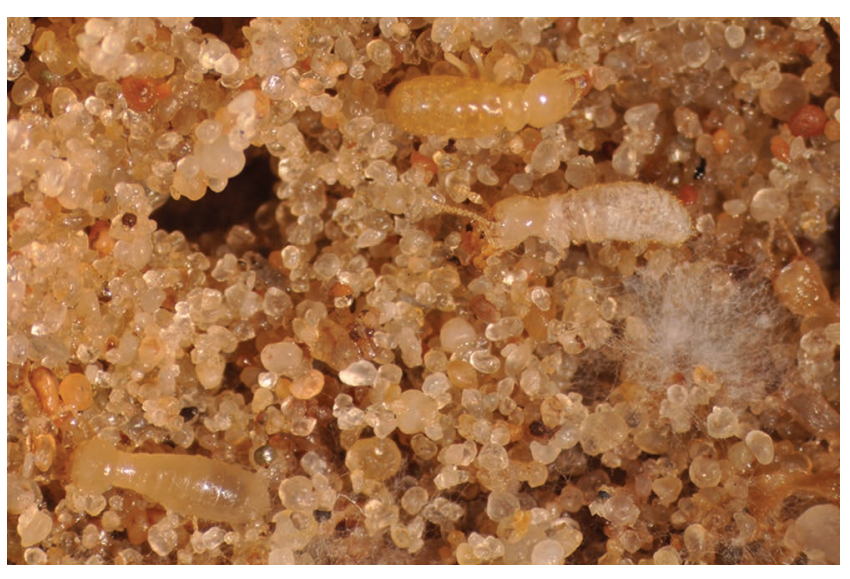

Figure 3. Initial stage of mould growth on termite body.

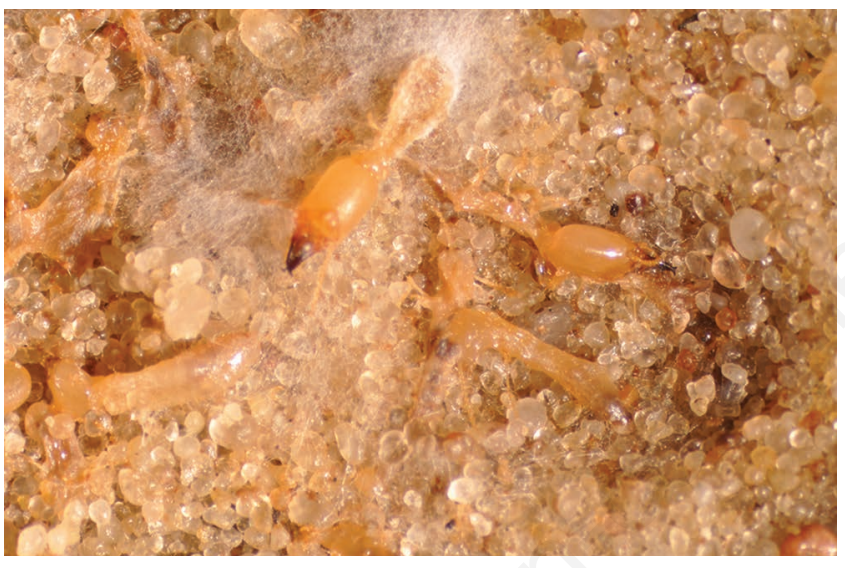

Figure 4. Advanced stage of mould growth on termite body.

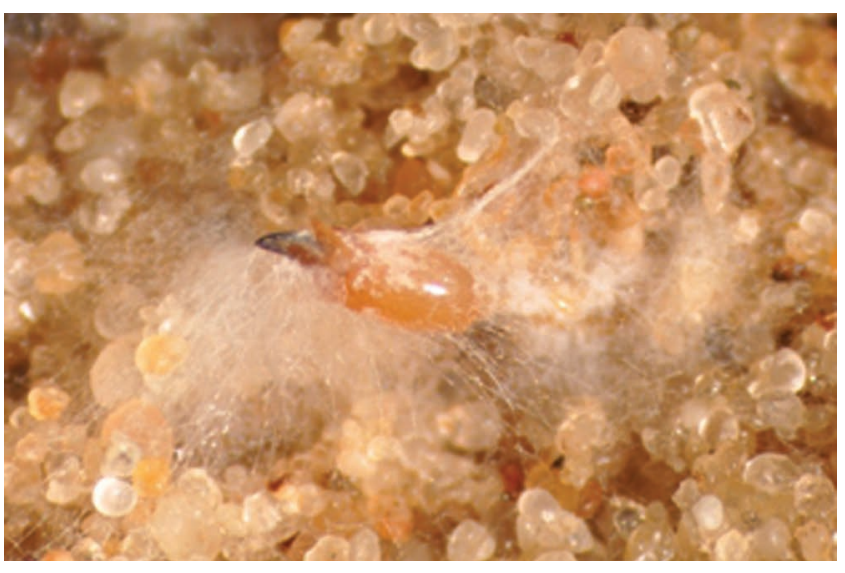

Figure 5. Very advanced stage of mould growth on termite body. used against whiteflies (Homoptera: Aleyrododea) and roundworms (Nematodes) (Mazurkiewicz-Zapałowicz, 2006; Zimmerman, 2008).

The growth of mould fungi in test containers caused death of whole termite colonies. Some fungi species isolated from colonies were found also in the nest. In test containers other fungi species were also found, but were not found in the main nest.

Appearance of the mould fungi in the isolated test colonies was probably caused by introduction of the already infected termites with pathogens. The possibility that termites infected sterile environments with spores attached to the cuticles cannot be excluded. In test colonies the following species were found: Trichoderma viride, Mucor himeralis (Wehmer), Rhizopus nigricans (Ehrenberg) and Aspergillus sp. In test colonies with domestic and exotic wood, T. viride, Aspergillus flavus (Link), Alternaria sp., $P$. verucosum and Fusarium sp. were recognisable. One of the exotic wood samples showed probable appearance of Aspergillus ustus (Thom et Church) (Figure 5). Test colonies containing samples of wood-based materials showed the following species: $T$. viride, $M$. himeralis, $R$. nigricans and Aspergillus sp. Except for the species coming from the main nest, common mould species appeared probably during preparations or later maintenance and observations of the colonies. Most frequently repeating species were T. viride and Aspergillus sp. fungi. These fungi were present in the main nest; colonies were probably infected by the insects.

\section{References}

ANONYMOUS, 2005 - PN-EN 117: 2005 (U) Środki ochrony drewna Oznaczanie wartości owadobójczej przeciwko Reticulitermes santonensis de Feytaud metoda laboratoryjna.

ANONYMOUS, 2008 - ASTM D 3345-08 US: Standard test method for laboratory evaluation of wood and other cellulosic materials for resistance to termites. - ASTM International, West Conshohocken, PA.

BECKER G., FRANK M., LENZ M., 1969 - Die Giftwirkung von Aspergillus flavus-Stammen auf Termiten in Beziehung zu ihrem Aflatoxin-Gehalt. - Z. Ang. Zool. 56: 451-464.

BOUCIAS D.G., PENDLAND J.C., 1998 - Principles of insect pathology. Klewer Academic Publishers, Boston: 537.

BROWNOLD E., FLANDERS S., 2005 - The effect of Trichoderma harzianum on honeybee survival. - New York State Integrated Pest Management Program. Available from: http://nysipm.cornell.edu/ grantspgm/projects/proj97/fruit/brownold.asp

GRZYWNOWICZ K., 2002. - Grzyby i ludzie-od entomomyklogii do mykotechnologii. - Wydawnictwo UMCS, Lublin: 72.

JAYASIMHA P., HENDERSON G., 2007 - Fungi Isolated from Integument and Guts of Coptotermes formosanus and Their Antagonistic Effect on Gleophyllum trabeum. - Sociobiology 49: 135-141.

LENZ M., 2005 - Biological control in termite management: the potential of nematodes and fungal pathogens, in Proc. Fifth International Conference on Urban Pests, Malaysia: 47-52.

LOHMEYER T.R., KÜNKELE U., 2006 - Grzyby, rozpoznawanie i zbieranie. - Parragon Books: 249.

MAZURKIEWICZ-ZAPAŁOWICZ K., 2006. - A jednak metabolity grzybowe mogą by także dobrodziejstwem ludzkości [w]. In: GRAJEWSKIEGO J. (Ed.), Mikotoksyny i grzyby pleśniowe - zagrożeniem dla człowieka i zwierząt. - Wydawnictwo Uniwersytetu Kazimierza Wielkiego, Bydgoszcz: 185.

MEIKLE W.G., MERCADIER G., ROSENGAUS R.B., KIRK A.A., DEROUANÉ F., QUIMBY P.C., 2005 - Evaluation of an entomopathogenic fungus, Paecilomyces fumosoroseus (Wize) Brownand Smith (Deuteromycota: Hyphomycetes) obtained from Formosan subterranean termites (Isoptera: Rhinotermitidae). - J. Appl. Entomol. 129: $315-322$. 
MILNER J.R., 2000 - Current status of Metarhizium mycoinsecticide in Australia. - Biocontrol News Inf. 21: 47-50.

MYLES T.G., 2002 - Isolation of Metarhizium anisopliae (Deuteromycotina: Hyphomycetes) from Reticulitermes flavipes (Isoptera: Rhinotermitdae) with convenient methods for its culture and collection of conidia. - Sociobiology 40: 257-262.

PIONTEK M., 1999 - Atlas - Grzyby pleśniowe, Wydawnictwo Zielonogórskie, Zielona Góra.

RAPER K.B., THOM CH., FENNEL D.I., 1949 - Manual of the Penicillia. - The Williams and Wilkins Company, Baltimore, MD: 486.

ROJAS M.G., MORALES-RAMOS J.A., KLICH M.A., WRIGHT M., 2001 Three fungal species isolated from Coptotermes formosanus (Isoptera: Rhinotermitidae) bodies, carton material, and infested wood. - Fla. Entomol. 84: 156-158.

ROSENGAUS R.B., GULDIN M.R., TRANIELLO J.F.A., 1998 - Inhibitory effect of termite fecal pellets on fungal spore germination. - J. Chem. Ecol. 24: 1697-1705.
SAWICKI A., 2010 - Grzyby w walce z p drakami. - Trybuna Leśnika 2: 6-8. SHIMIZU S., YAMAJI M., 2003 - Effect of density of the termite, Reticulitermes speratus Kolbe (Isoptera: Rhinotermitidae), on the susceptibilities to Metarhizium anisopliae. - Jpn. J. Appl. Entomol. Zool. 38: 125-135.

THOM C.H., RAPER K.B., 1945. - A manual of the Aspergilli. - The Williams and Wilkins Company, Baltimore, MD: 176.

YANAGAWA A., YOKOHARI F., SHIMIZU S., 2010 - Influence of fungal odor on grooming behavior of the termite, Coptotermes formosanus. - J. Insect Sci. 10: 141.

ZIMMERMANN G., 2008 - The entomopathogenic fungi Isaria farinosa (formerly Paecilomyces farinosus) and the Isaria fumosorosea species complex (formerly Paecilomyces fumosoroseus): biology, ecology and use in biological control. - Biocontrol Sci. Technol. 18: 865-901.

ZOBERI M.H., GRACE J.K., 1990 - Fungi associated with subterranean termite Reticulitermes flavipes in Ontario. - Mycologia 82: 289-284. 